Article

\title{
A New $\beta$-Galactosidase from the Antarctic Bacterium Alteromonas sp. ANT48 and Its Potential in Formation of Prebiotic Galacto-Oligosaccharides
}

\author{
Shangyong $\mathrm{Li}^{1}$, Xiangjie Zhu ${ }^{2} \mathbb{D}$ and Mengxin Xing ${ }^{2, *}$ \\ 1 Department of Pharmacology, School of Basic Medicine, Qingdao University, Qingdao 266071, China; \\ lisy@qdu.edu.cn \\ 2 Yellow Sea Fisheries Research Institute, Chinese Academy of Fishery Sciences, Qingdao 266071, China; \\ zhuxiangjie1204@163.com \\ * Correspondence: 15865506157@126.com; Tel.: +86-532-85819525
}

Received: 29 September 2019; Accepted: 20 October 2019; Published: 23 October 2019

\begin{abstract}
As an important medical enzyme, $\beta$-galactosidases catalyze transgalactosylation to form prebiotic Galacto-Oligosaccharides (GOS) that assist in improving the effect of intestinal flora on human health. In this study, a new glycoside hydrolase family 2 (GH2) $\beta$-galactosidase-encoding gene, galA, was cloned from the Antarctic bacterium Alteromonas sp. ANT48 and expressed in Escherichia coli. The recombinant $\beta$-galactosidase GalA was optimal at $\mathrm{pH} 7.0$ and stable at $\mathrm{pH} 6.6-7.0$, which are conditions suitable for the dairy environment. Meanwhile, GalA showed most activity at $50{ }^{\circ} \mathrm{C}$ and retained more than $80 \%$ of its initial activity below $40{ }^{\circ} \mathrm{C}$, which makes this enzyme stable in normal conditions. Molecular docking with lactose suggested that GalA could efficiently recognize and catalyze lactose substrates. Furthermore, GalA efficiently catalyzed lactose degradation and transgalactosylation of GOS in milk. A total of $90.6 \%$ of the lactose in milk could be hydrolyzed within 15 min at $40{ }^{\circ} \mathrm{C}$, and the GOS yield reached $30.9 \%$. These properties make GalA a good candidate for further applications.
\end{abstract}

Keywords: $\beta$-galactosidase; galactooligosaccharides; daily industry

\section{Introduction}

$\beta$-Galactosidases (EC 3.2.1.23) are a type of glycoside hydrolase $(\mathrm{GH})$, catalyzing lactose hydrolysis and transgalactosylation. As a commonly used medical enzyme, $\beta$-galactosidase has been widely used to decompose lactose into galactose and glucose in the dairy industry [1]. In addition, $\beta$-galactosidase can also produce Galacto-Oligosaccharides (GOS) via transglycosylation during the hydrolysis of lactose or other structurally related galactosides [2,3]. Hence, $\beta$-galactosidases can be widely used in applications related to nutrition and food processing [1].

To date, $\beta$-galactosidases have been purified and characterized from various organisms, such as bacteria [4-7], fungi [8,9], yeast [10,11], plants [12], and mammals [13]. Based on functional similarities, $\beta$-galactosidases can be classified into four GH families (GH 1, 2, 35, and 42) in the CAZy database $[14,15]$. Structurally, the most extensively studied $\beta$-galactosidase is lacZ from Escherichia coli that belongs to GH family 2 [16]. It is basically a tetramer of four identical amino acid chains, each of which consists of five domains. The third domain is an eight-stranded $\alpha / \beta$ barrel (TIM-type barrel), which acts as the active site made up of two different tetramer subunits [1,17].

The hydrolytic activity of $\beta$-galactosidase has been utilized in the food industry for decades to assist in absorbing undigested lactose [2]. Currently, many children and adults worldwide, especially in East Asia, are facing the problem of lactose dyspepsia and intolerance caused by lactase deficiency. $[13,18,19]$. 
The decreased activity or reduced synthesis of $\beta$-galactosidase, which occurs in the small intestine, is the reason behind these disorders $[1,13]$. About $2 \%-5 \%$ of infants within the first one to three months of life suffer from cow milk-protein intolerance. Approximately $70 \%$ of the world's adult population cannot digest lactose, of which more than $90 \%$ are East Asians [20]. People who suffer from lactose intolerance only consume dairy-fermented products that comprise either no or very little lactose [21]. For overcoming the limitations imposed by lactose intolerance, $\beta$-galactosidases derived from bacteria and fungi can be used to make milk almost lactose-free by degrading the lactose in milk, which is sweeter than regular milk $[13,18]$. In addition, people take medicines containing $\beta$-galactosidase before consuming milk products, which can also effectively reduce lactose concentration $[19,20]$. Furthermore, in the food industry, the hydrolytic activity of $\beta$-galactosidases is also utilized for reducing crystallization in ice creams and condensed milk [22].

The transgalactosylation activity of $\beta$-galactosidase has also attracted considerable attention in recent years for the production of GOS, nondigestible prebiotics that assist in improving the effect of intestinal flora on human health, and stimulating the growth of beneficial bacteria, such as bifidobacteria and lactobacilli [1]. It is well known that the growth of probiotics can reduce the number of pathogenic bacteria, improve immunity, and prevent cancer [3]. Some research exhibited how gut microbiota or potential probiotics can exert therapeutic interventions by decreasing gut permeability or stimulating host homeostasis of the mucosal immune system and then regulating microbiota dysbiosis to a healthy state [23]. And in another study, information of microbial disorder-related inflammatory bowel disease was added and demonstrated how Rifaximin and Mutaflor exhibited synergic anti-inflammatory and therapeutic effects on acetic acid-induced colitis in rats [24]. Moreover, some synthetic bifunctional salts provide better biological control of pathogenic bacteria and thus serve as a therapeutic strategy for some microbial infections or disorders [25]. Additionally, GOS has various health benefits for the human body, such as decreasing the $\mathrm{pH}$ of human feces, preventing cariogenicity, and reducing serum cholesterol levels [1,2]. Therefore, in the food industry, GOS are used as an ingredient in infant milk and cereal-based food, soft drinks, and low-calorie sweeteners. At present, commercial GOS is produced via enzymatic synthesis ( $\beta$-galactosidases) for good stereoselectivity and regioselectivity [26].

Thermostable activity is indispensable for the practical application of enzymes, as it reduces the risk of contamination, increases reaction velocities, decreases product inhibition, prolongs half-lives, and improves the solubility of substrates $[4,26,27]$. In this study, a new $\beta$-galactosidase from Alteromonas sp. ANT48, a strain isolated from the surface seawater of the Antarctic, has been purified and characterized. Subsequently, the enzyme was used to catalyze the transglycosylation reaction to produce oligosaccharides, for evaluating the potential application in GOS biosynthesis.

\section{Results}

\subsection{Cloning and Sequence Analysis of GalA}

The marine bacterium Alteromonas sp. ANT48 was isolated from the surface seawater of Drake Passage near the Great Wall Station in the Antarctic. The $16 \mathrm{~S}$ rDNA of Alteromonas sp. ANT48 showed high homology (99.63\%) with Alteromonas sp. NJSX39 (accession number EF061431). The $\beta$-galactosidase gene, galA, from Alteromonas sp. ANT48, contained an intact open reading frame (ORF) of $3120 \mathrm{bp}$ and encoded a protein consisting of 1039 amino acids. The theoretical isoelectric point (pI) and molecular weight (Mw) of $\beta$-galactosidase GalA were 5.27 and $117.40 \mathrm{kDa}$, respectively. According to a search of the Carbohydrate-Active enZymes (CAZy) database, conservative domain database in NCBI (CDD), and Pfam database, GalA was considered a new $\beta$-galactosidase of the glycoside hydrolase (GH) family 2.

A phylogenetic tree was created based on the amino acid sequences of GalA and other reported $\beta$-galactosidases from GH1, GH2, GH35, and GH42 families (Figure 1). As expected, the resulting tree showed that GalA belonged to a group of enzymes designated as GH family 2 (shown as group I in Figure 1), while other $\beta$-galactosidases belonged to the group of enzymes classified as GH family 1 or GH35 (shown as group II in Figure 1) and the GH42 family (shown as group III in Figure 1). 
In the cluster of GH2, GalA showed highest identity with other $\beta$-galactosidases from the genus Alteromonas. In addition, GalA also showed closer phylogenetic relationship with $\beta$-galactosidases from Psychromonas sp., Klebsiella pneumonia, Enterobacter cloacae, and Escherichia coli, exhibiting 52\%, $47 \%, 48 \%$, and $49 \%$ identities, respectively.

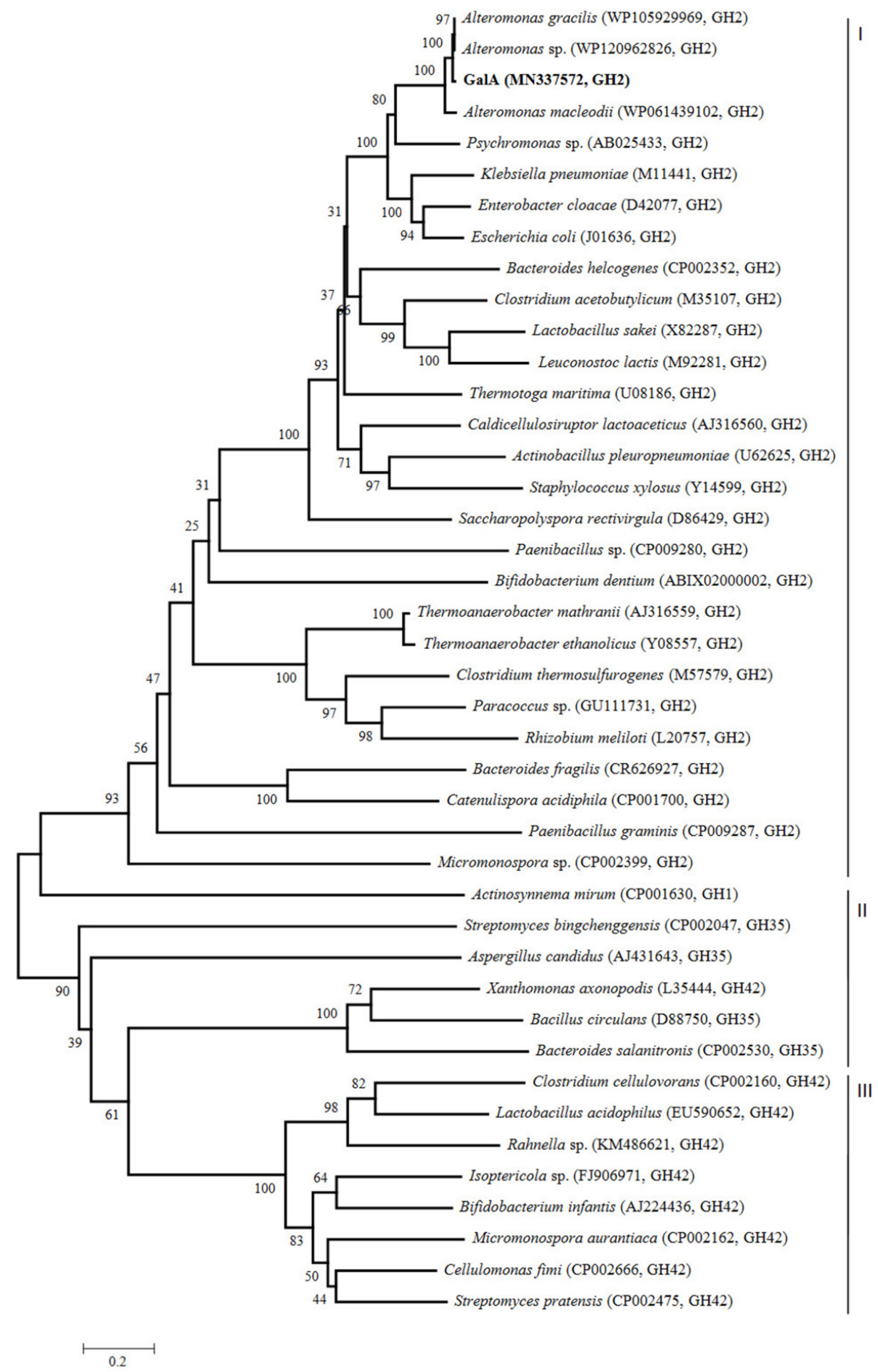

Figure 1. Evolutionary tree of $\beta$-galactosidases amino acid sequences based on the neighbor-joining method. The phylogenetic tree (1000 bootstraps) was constructed using the MEGA 6.0 program. 

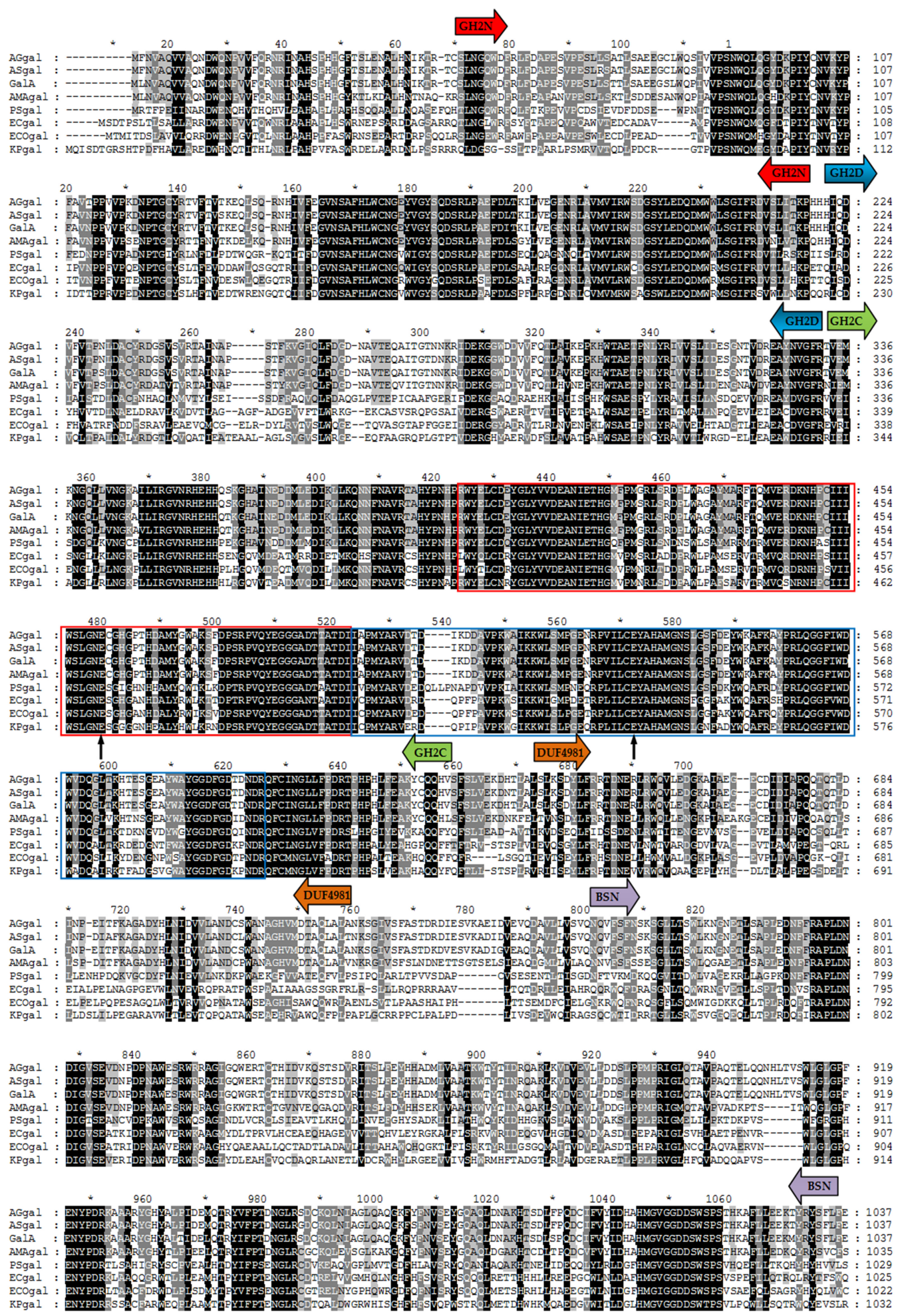

Figure 2. Comparison of the sequence of GalA with those of related $\beta$-galactosidases from GH2: AGgal from A. gracilis (WP105929969), ASgal from Alteromonas sp. (WP120962826), AMAgal from A. macleodii (WP061439102), PSgal from Psychromonas sp. (AB025433), ECgal from E. cloacae (D42077), ECOgal from E. coli (J01636), and KPgal from K. pneumoniae (M11441). The acid-base active sites and the consensus nucleophilic region are indicated by red and blue bands, respectively. The catalytic amino acids are marked by the black arrows. The domains of the GH2 are indicated by arrows of different colors. 
Multiple alignments of the amino acid sequences were used to further analyze the conserved and catalytic domains (Figure 2). According to the Pfam database, three conserved structural domains occurred in GalA, consisting of the glyco hydro $2 \mathrm{~N}$ domain $(\mathrm{GH} 2 \mathrm{~N}$, sugar binding domain, amino acid (aa) 47-aa218), glyco hydro 2 domain (GH2D, aa220-aa332), and glyco hydro 2 C domain (GH2C, TIM barrel domain, aa334-aa628). Among them, GH2C was the only domain related to the catalytic activity of GalA, which contained acid-base active sites and the conserved nucleophilic region with a high similarity to the typical $\beta$-galactosidases of the GH family 2 , such as in E. coli. The proposed active site glutamic acid residues (GLU-460 and GLU-536) were also indicated after comparing with $\beta$-galactosidases from E. coli. However, the two other structural domains of GalA, domain of unknown function (DUF4981, aa639-aa726) and the Bgal small N domain (BSN, aa760-aa1036), showed low homology with other $\beta$-galactosidases from different bacteria. The results described above identified GalA as a new member of the GH family 2.

According to the NCBI database, the sequences of $\beta$-galactosidase from the Alteromonas genus were fewer than those from other bacteria, and studies on the isolation and characterization of this enzyme from the Alteromonas genus were also limited. In this study, a new $\beta$-galactosidase from Alteromonas sp. ANT48, GalA, was purified and characterized. Sequence analysis showed that GalA belonged to the GH family 2 with five structural domains, namely GH2N, GH2D, GH2C, DUF4981, and BSN domains. Talens-Perales et al. structurally divided the GH2 into five groups [28]. According to this classification, GalA was classified as DA (domain architecture) type 3 with Bgal small $\mathrm{N}$ domain (BSN), linked to GH2C via a $\beta$-sandwich domain, while DA type 4 and 5 lacked the BSN domain. Previous studies have demonstrated that DA type 3 exhibited high transgalactosylation activity and synthesized $\beta-(1,3)$ and $\beta-(1,6)$ galacto-oligosaccharides [28,29], while DA type 5 synthesized $\beta-(1,4)$ GOS [30,31]. Furthermore, using multiple alignments and docking analysis, both Glu460 and Glu536 in the GH2C (TIM barrel domain) of GalA were identified as catalytic residues; the consensus nucleophilic regions were also detected, which confirmed that the TIM barrel domain contained the catalytic sites and most of them participated in the formation of the active pocket [28]. Further docking analysis demonstrated that the highly hydrophilic semi-open pocket was on the catalytic domain of GalA, which is in agreement with the results of a previous study showing that the structure of the TIM barrel domain was suitable for hydrolyzing polysaccharides by modifying the catalytic conformation from cleft-shaped to pocket-shaped [30,32,33]. Additionally, most $\beta$-galactosidases from the Antarctic bacteria belonged to GH2 or GH42 [34-37]. However, in contrast to other $\beta$-galactosidases from Antarctic bacteria, GalA was not a cold-adapted enzyme, although its amino acid sequence had high homology with that from Psychromonas sp., and its catalytic activity was similar to that of mesophilic bacteria. Therefore, GalA was considered an interesting enzyme for further investigation.

\subsection{Expression, Purification, and Characterization of GalA}

The E. coli BL21-pET28a-GalA strain was grown in LB broth and induced by IPTG. The crude enzymes were harvested by centrifugation and purified by a Ni-Sepharose affinity column. The yield of GalA reached to $127 \mathrm{mg} / \mathrm{L}$. After purification, the specific activity of GalA was $237.6 \mathrm{U} / \mathrm{mg}$ with 2-Nitrophenyl- $\beta$-d-galactopyranoside (ONPG) as substrate. SDS-PAGE analysis was used to determine the Mw of the purified enzyme. As shown in Figure 3, only a single clear band on the gel with an approximate $\mathrm{Mw}$ of $110 \mathrm{kDa}$ was observed, which was corresponding to its theoretical $\mathrm{Mw}(117.4 \mathrm{kDa})$. 


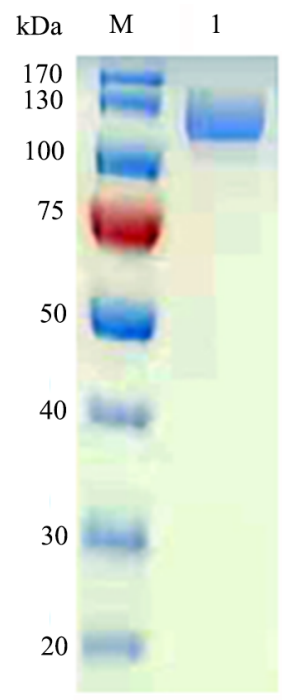

Figure 3. SDS-PAGE analysis of the recombinant GalA. Lane M, protein marker; Lane 1, the purified GalA.

The optimum temperature for recombinant GalA was $50{ }^{\circ} \mathrm{C}$ (Figure $4 \mathrm{~A}$ ). Importantly, GalA maintained relatively high activity $(>73.6 \%)$ at the temperature range of $30-50^{\circ} \mathrm{C}$. As shown in Figure $4 \mathrm{C}$, more than $80 \%$ of the enzymatic activity remained after incubation below $40^{\circ} \mathrm{C}$. Meanwhile, the half-life time $\left(\mathrm{t}_{1 / 2}\right)$ of GalA at $50^{\circ} \mathrm{C}$ and $60^{\circ} \mathrm{C}$ is $76.5 \mathrm{~min}$ and $27.6 \mathrm{~min}$, respectively. The optimum $\mathrm{pH}(6.6-7.0)$ of GalA that is appropriate to the dairy environment will greatly facilitate its further application. Herein, the optimal reaction pH of GalA was 7.0 (Figure 4B). Meanwhile, GalA was stable in a pH range between 6.6 and 9.6, especially between 6.6 and 7.0 (Figure $4 \mathrm{D}$ ), which will greatly enhance its application potential.

A

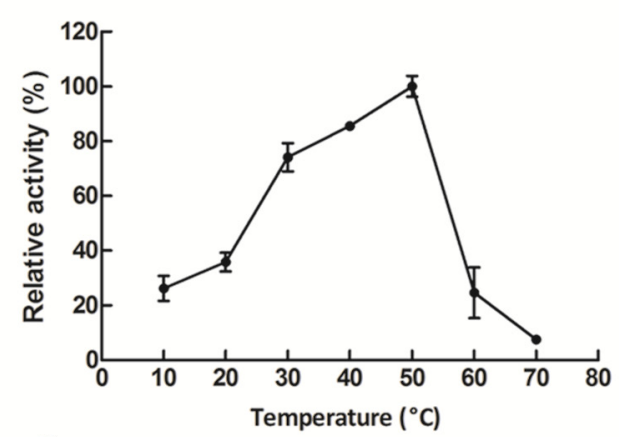

C

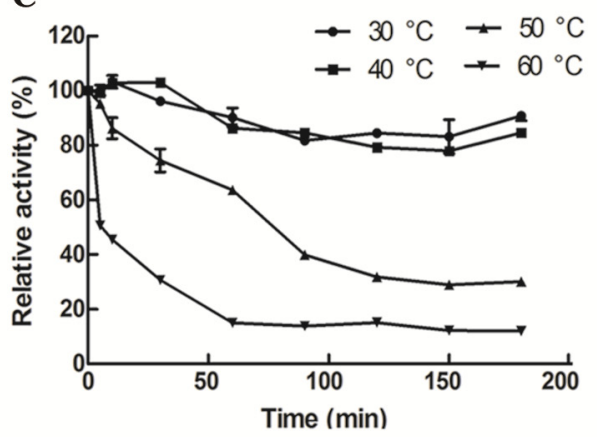

B

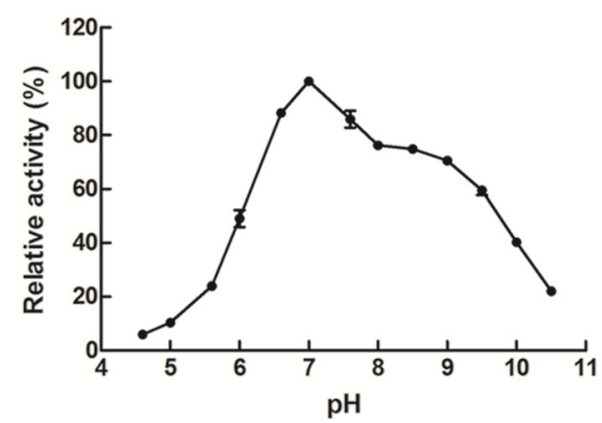

D

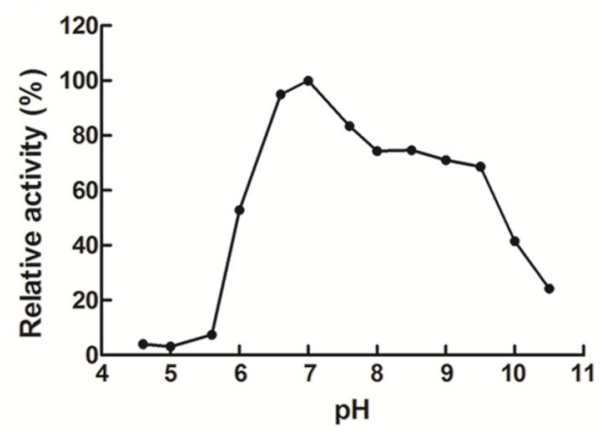

Figure 4. Effect of temperature and $\mathrm{pH}$ on GalA. (A) The optimal temperature of GalA; (B) the optimal $\mathrm{pH}$ of GalA; (C) the thermal-stability of GalA; and (D) the pH stability of GalA. 
Reactions were carried out to test the impact of metal ions, EDTA, and SDS on the activity of GalA. As shown in Table 1, in general, enzymatic activity was activated by $\mathrm{Mn}^{2+}, \mathrm{Mg}^{2+}$, and $\mathrm{Fe}^{3+}$, and inhibited by $\mathrm{Na}^{+}, \mathrm{K}^{+}, \mathrm{Li}^{+}, \mathrm{NH}_{4}{ }^{+}, \mathrm{Zn}^{2+}, \mathrm{Cu}^{2+}, \mathrm{Fe}^{2+}, \mathrm{Ba}^{2+}, \mathrm{Co}^{2+}, \mathrm{Ca}^{2+}, \mathrm{Al}^{3+}$, and EDTA, as well as SDS (Table 1).

Table 1. Effects of metal ions, EDTA and SDS on the activity of GalA.

\begin{tabular}{ccc}
\hline Reagent Added & Concentration $(\mathbf{m M})$ & Relative Activity $(\%)$ \\
\hline $\mathrm{None}$ & - & $100.0 \pm 0.0$ \\
$\mathrm{NaCl}$ & 10 & $54.9 \pm 2.3$ \\
$\mathrm{SDS}$ & 1 & $17.9 \pm 3.7$ \\
$\mathrm{EDTA}$ & 1 & $26.2 \pm 3.9$ \\
$\mathrm{Al}_{2}\left(\mathrm{SO}_{4}\right)_{3}$ & 1 & $21.7 \pm 3.0$ \\
$\mathrm{KCI}$ & 1 & $67.5 \pm 0.9$ \\
$\mathrm{CuSO}_{4}$ & 1 & $8.1 \pm 1.0$ \\
$\mathrm{FeCI}_{2}$ & 1 & $77.8 \pm 4.2$ \\
$\left(\mathrm{NH}_{4}\right)_{2} \mathrm{SO}_{4}$ & 1 & $93.7 \pm 1.7$ \\
$\mathrm{MnSO}_{4}$ & 1 & $164.1 \pm 1.4$ \\
$\mathrm{Li}_{2} \mathrm{SO}_{4}$ & 1 & $64.7 \pm 2.0$ \\
$\mathrm{ZnCI}_{2}$ & 1 & $77.2 \pm 2.1$ \\
$\mathrm{BaCI}_{2}$ & 1 & $26.9 \pm 5.1$ \\
$\mathrm{CoCI}_{2}$ & 1 & $69.4 \pm 2.2$ \\
$\mathrm{MgCI}_{2}$ & 1 & $149.0 \pm 3.8$ \\
$\mathrm{CaCI}_{2}$ & 1 & $82.9 \pm 2.2$ \\
$\mathrm{FeCI}_{3}$ & 1 & $142.7 \pm 1.0$
\end{tabular}

Notes: $\overline{\text { Activity without addition of chemicals was defined as } 100 \% \text {. Data are shown as means } \pm \operatorname{SD}}(n=3)$.

The substrate specificity of GalA was determined using five different substrates. As shown in Table 2, the enzyme was preferred ONPG as its substrate. Meanwhile, GalA showed 14.6\% relative activity towards 4-Nitrophenyl- $\beta$-d-galactopyranoside (PNPG) and no activity to other substrates.

Table 2. Substrate specificity of the recombinant GalA.

\begin{tabular}{cc}
\hline Substrate & Relative Activity (\%) ${ }^{\mathbf{1}}$ \\
\hline 2-Nitrophenyl- $\beta$-d-galactopyranoside (ONPG) & $100 \pm 7.9$ \\
4-Nitrophenyl- $\beta$-d-galactopyranoside (PNPG) & $14.6 \pm 3.1$ \\
4-Nitrophenyl- $\alpha$-d-galactopyranoside & 0 \\
4-Nitrophenyl- $\beta$-d-glucopyranoside & 0 \\
4-Nitrophenyl- $\beta$-d-xylopyranoside & 0 \\
\hline
\end{tabular}

${ }^{1}$ Activity of ONPG substrate was defined as 100\%. Data are shown as means $\pm \operatorname{SD}(n=3)$.

\subsection{Docking Analysis of GalA}

The three-dimensional (3D) model of the GalA was constructed based on the homologues structure of $\beta$-galactosidases from E. coli (PDB ID: 6CVM) with an identity of $49.3 \%$, and lactose was docked into the GalA. The docking parameters are shown in Table 3. Molecular docking indicates that lactose binds to a semi-open pocket on the catalytic domain of the protein, which has a good fit and geometric complementarity. The pocket is highly hydrophilic due to its proximity to the solvent environment. Lactose itself is also a hydrophilic molecule, thus facilitating its binding (Figure 5A). The $\beta$-galactosidase catalyzed the hydrolysis of lactose and transglycosylation to form GOS. The recombinant GalA exhibited high catalytic activity (237.6 U/mg) and efficiently degraded the lactose in milk. To identify the key residues for substrate recognition, the protein-substrate interactions were analyzed in ligplot. As shown in Figure 5B, the residues ASN-103, ASP-201, GLU-460, TYR-502, and GLU-536 form hydrogen bonds with lactose, respectively. Meanwhile, there are seven amino acids (VAL-104, HIS-417, MET-501, HIS-539, TRP-567, PHE-600, and TRP-1015) forming hydrophobic 
interaction towards lactose. These results suggested that GalA has a strong binding ability towards lactose to facilitate hydrolysis.

Table 3. Docking parameters in Autodock software.

\begin{tabular}{cc}
\hline Parameters & Value \\
\hline X coordinate of the center & 81.551 \\
Y coordinate of the center & 130.691 \\
Z coordinate of the center & 103.074 \\
Size in the X dimension & $24 \AA$ \\
Size in the Y dimension & $24 \AA$ \\
Size in the Z dimension & $24 \AA$ \\
Maximum number of binding modes to generate & 9 \\
Maximum energy difference between the best & $4 \mathrm{kcal} / \mathrm{mol}$ \\
\hline
\end{tabular}

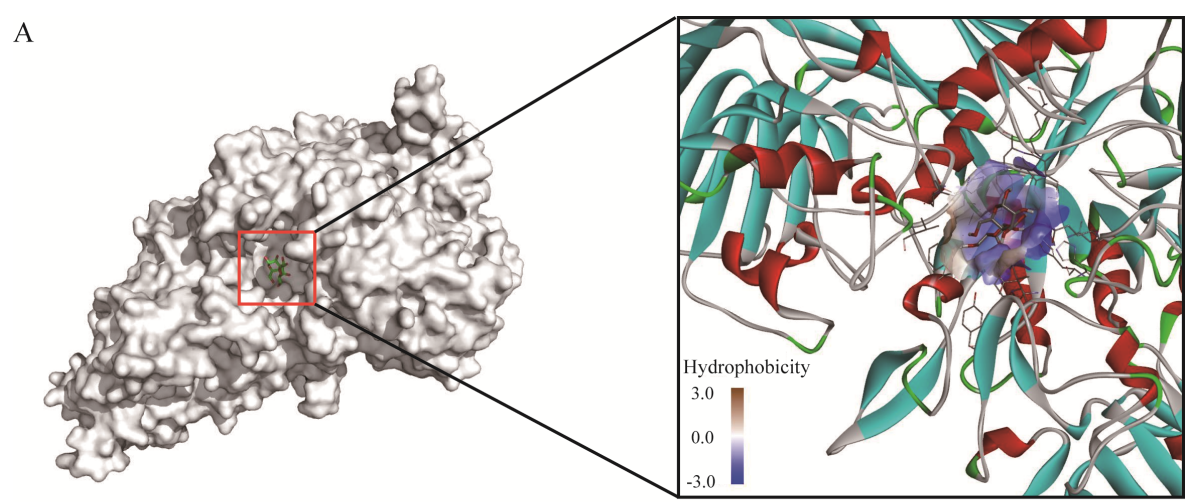

B

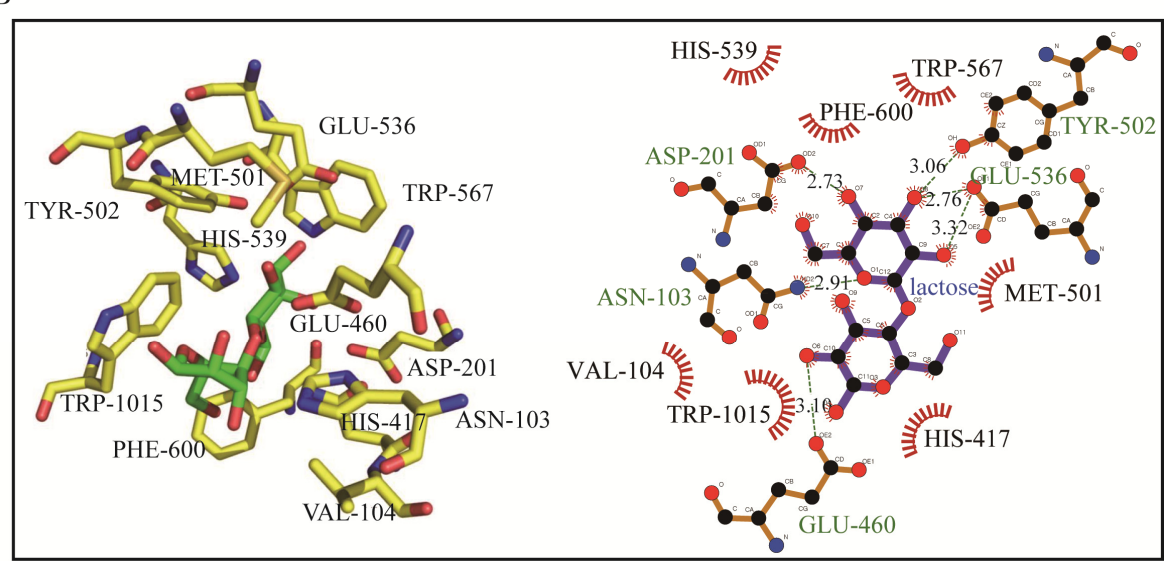

Figure 5. Molecular docking of GalA with lactose. (A) Overall and hydrophobicity analysis. (B) Schematic representation showing enzyme/substrate interactions of GalA. Hydrogen bonds are dotted lines and hydrophobic interactions are represented by "arcs".

\subsection{Hydrolysis of Lactose in Milk}

$\beta$-Galactosidases catalyze the lactose hydrolysis and transgalactosylation to form GOS. To determine the lactose degrading and transgalactosylation activity of GalA, the products of GalA at different reaction times were analyzed by thin layer chromatography (TLC) (Figure 6A). As the reaction processing, lactose can be degraded into monomers. Meanwhile, GOS can appear clearly on the TLC plate. Finally, when the reaction time is extended to $600 \mathrm{~min}$, lactose was completely hydrolyzed by GalA. There results indicated that GalA could efficiently play lactose degrading and transgalactosylation activity. Thus far, $\beta$-galactosidases are commercially used for the hydrolysis of lactose in dairy products, such as milk and cheese whey. In this study, we also determined 
the lactose-degrading effect in milk. As shown in Figure 6B, lactose in milk can be degraded fast. Meanwhile, GOS was formed along with the reaction processing. The reaction product at $15 \mathrm{~min}$ was further analyzed by size-exclusion high performance liquid chromatography (SE-HPLC) using a Superdex peptide $10 / 300^{\mathrm{TM}}$ column. As shown in Figure $6 \mathrm{C}, 90.6 \%$ of the lactose was hydrolyzed and the GOS yield was $30.9 \%$.

$\mathbf{A}$

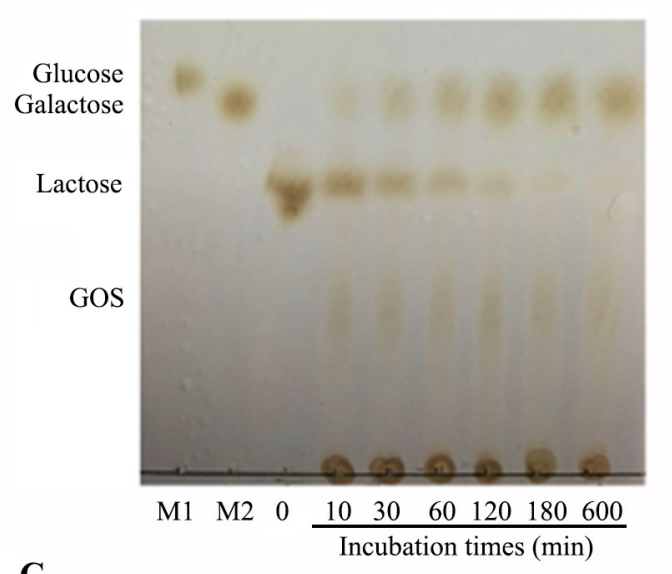

B

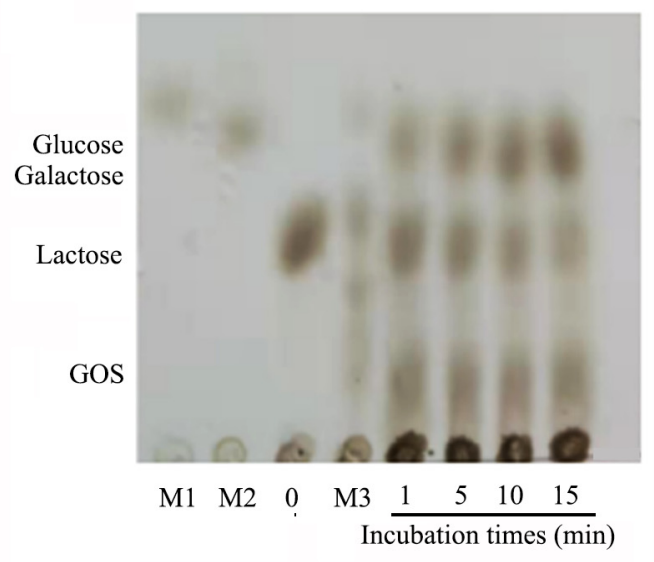

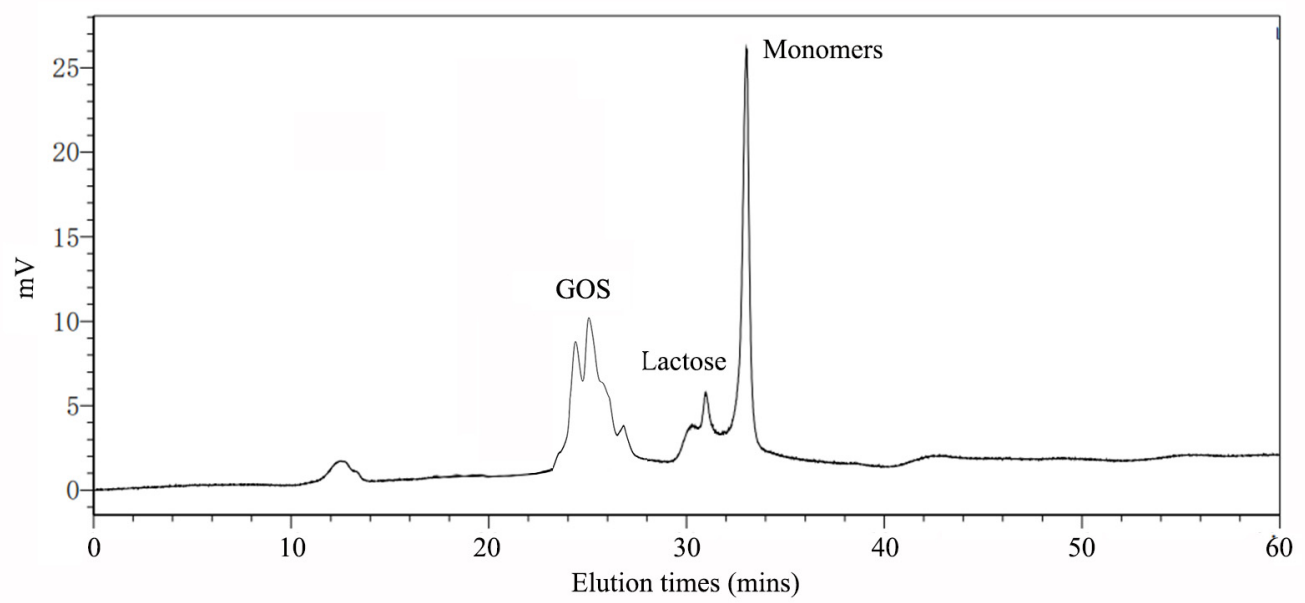

Figure 6. TLC and HPLC analysis of lactose and milk degrading by GalA. (A) TLC analysis of lactose degrading by GalA; (B) TLC analysis of milk degrading by GalA; and (C) HPLC analysis of GOS producing by GalA incubated for 15 min in milk.

More than $90 \%$ of the population in Eastern Asia exhibit varying degrees of lactose intolerance. $\beta$-Galactosidases catalyze the lactose hydrolysis and has been commercially used in the dairy industry. Although various $\beta$-galactosidases have been cloned and characterized, only a few of them could be used for commercial applications. Thus far, the major industrial $\beta$-galactosidases are obtained from the Aspergillus and Kluyveromyces genera, which exhibit many excellent properties [38,39], such as an optimal $\mathrm{pH}$ (6.6-7.0) suitable to the dairy environment. This study indicated that GalA had optimal activity at $\mathrm{pH} 7.0$ and was stable at $\mathrm{pH}$ 6.6-7.0, which corresponded with its application to milk. Thermostability is another important limitation of an enzyme application. A thermostable $\beta$-galactosidase gene bgaB was over-expressed in B. subtilis WB600 [40]. This enzyme was considered as one of the most thermally stable $\beta$-galactosidase, with half-life times at 65 and $70{ }^{\circ} \mathrm{C}$ of 50 and $9 \mathrm{~h}$, respectively. In lactose hydrolysis, the maximum lactose degrading rate was $100 \%$ when using recombinant $\mathrm{BgaB}$ at $65^{\circ} \mathrm{C}$ for $120 \mathrm{~min}$. In this study, GalA could keep stable under $40{ }^{\circ} \mathrm{C}$, which makes maintaining enzyme activity at normal temperatures possible (Figure $4 \mathrm{C}$ ). Even GalA does 
not have the same thermal stability as $\mathrm{BgaB}, 90.6 \%$ of the lactose in milk could hydrolysis within $15 \mathrm{~min}$ at $40{ }^{\circ} \mathrm{C}$. Comparing with other $\beta$-galactosidases from various bacteria, the cold-adapted $\beta$-galactosidase from P. haloplanktis, which hydrolyzed $26 \%$ of the lactose in milk at $25^{\circ} \mathrm{C}$ under $30 \mathrm{~min}$, this enzyme showed a lower apparent optimum temperature of activity and exhibited a weaker thermal stability [41]. Another $\beta$-galactosidase from Lactobacillus pentosus shows an optimal $\mathrm{pH}$ at 7.5-8.0 and obtain a maximum yield of 31\% GOS of total sugars at $78 \%$ lactose conversion [42]. A recombinant $\beta$-galactosidase from Lactobacillus plantarum WCFS1, had a yield of $41 \%(\mathrm{w} / \mathrm{w})$ of total sugars at $85 \%$ lactose conversion [43]. These comparisons indicated that GalA is suitable for lactose treatment in the dairy industry.

Another important feature of $\beta$-galactosidase is the transgalactosylation reaction to form GOS. Being a nondigestible prebiotic, GOS could assist in improving the effect of intestinal flora on human health and stimulating the growth of beneficial bacteria such as bifidobacteria and lactobacilli [1]. The growth of probiotics can improve immunity and prevent the growth of pathogenic bacteria [3]. Meanwhile, GOS showed various benefits for the human health, such as decreasing the $\mathrm{pH}$ of human feces, preventing cariogenicity, and reducing serum cholesterol levels [1,2]. However, the transgalactosylation activity of $\beta$-galactosidases are different. The range of oligosaccharide varies between $1 \%$ and $45 \%$ in GOS that further depends on the total amount of saccharides and on the enzyme source of the enzyme [1]. Recently, many studies aimed to find new $\beta$-galactosidases to achieve higher GOS content and quality. Currently considered $\beta$-galactosidases from Bacillus species were investigated to obtain high GOS production [1]. $\beta$-galactosidase from $B$. longum BCRC 15708 produced GOSs (mainly trisaccharides) [44]. Recombinant $\beta$-galactosidase from $B$. infantis in Pichia pastori was widely used for commercial production of GOS. The conversion rates of transgalactosylation were about $25.2 \%$, and the maximum GOS yield was $40.6 \%$ [45,46]. In this study, GOS showed a high conversion rate $(30.9 \%)$, which will greatly improve its application potential.

\section{Material and Methods}

\subsection{Bacterial Strains and Cell Culture Conditions}

The seawater samples were collected from the surface layer of the Drake Passage near the Great Wall Station in the Antarctic. Bacteria in the seawater sample were collected by filtering $5 \mathrm{~L}$ of seawater onto $0.2 \mu \mathrm{m}$ pore size filters (Pall, Lane Cove, Australia) and then serially diluted to $10^{-6}$ and placed on Zobell 2216E medium (BD Difco, Franklin Lakes, NJ, USA). After incubation at $15^{\circ} \mathrm{C}$ and $25^{\circ} \mathrm{C}$ for 7 days, more than 180 strains were isolated, which were inoculated onto selective medium $(1 \%$ peptone, $1 \%$ yeast extract, $0.5 \%$ lactose, $2 \% \mathrm{NaCl}, 0.004 \% \mathrm{X}$-gal, $1.5 \%$ agar, $\mathrm{pH} 7.0)$ for screening the $\beta$-galactosidase producer. One of strains with high activity was identified as Alteromonas sp. ANT48 based on the full-length sequence of its $16 \mathrm{~S}$ rDNA and sequence alignment using the BLASTn algorithm program and MEGA 6.0. Alteromonas sp. ANT48 was grown in Zobell 2216E medium and was kept in $40 \%$ glycerol at $-80^{\circ} \mathrm{C}$.

\subsection{Sequence Analysis}

The sequences of two primers, gal3-CTAGCTAGCATGCTTAATGTTGCGCAAGT and gal4-CCGCTCGAGTTATATTGCTTCAAAAAGG, used for cloning of the Alteromonas sp. ANT48 gene GalA, were designed based on the sequence of the $\beta$-galactosidase gene from Alteromonas sp. strain R10SW13 (Genbank accession number WP120962826). BLASTn and BLASTp (NCBI) were used to investigate the sequence homologies and protein sequence alignments, CLUSTALX program was used to perform multiple alignment analysis of GalA, and the MEGA 7.0 software was used to construct the evolutionary tree. Additionally, the ORF finder in NCBI (https://www.ncbi.nlm.nih.gov/orffinder/) was used to identify the open reading frame and the $\mathrm{pI} / \mathrm{Mw}$ Tool (https://web.expasy.org/compute_pi/) was used to calculate the theoretical $\mathrm{pI}$ and $\mathrm{Mw}$ of GalA. Comparison of the results obtained using three 
databases, including CAZy (http://www.cazy.org/), CDD in NCBI (http://www.ncni.nlm.nih.gov/cdd), and Pfam database (https://pfam.xfam.org/), revealed the conserved and catalytic domains of GalA.

\subsection{Overexpression and Purification of Recombinant GalA}

For over-expression of the $\beta-1,3$ galactosidase GalA, expression primers (PgalA-EF and PgalA-ER) were used to amplify the genome of the Antarctic seawater bacterium Alteromonas sp. ANT48. The signal peptide and stop codons were removed in the designation of expression primers. Afterwards, the obtained galA gene was ligated into the vector pET-28a with the recognition sites Nco I and Xho I. Finally, the recombinant plasmid pET-28a-galA was translated into E. coli BL21 (DE3). The recombinant strains grew in TB broth with $30 \mu \mathrm{g} / \mathrm{mL}$ kanamycin at $37^{\circ} \mathrm{C}$. When the $\mathrm{OD}_{600}$ of recombinant $E$. coli BL21 (DE3)-pET-28a-galA reached 0.6-0.8, $0.1 \mathrm{mM}$ isopropyl $\beta$-D-thiogalactoside (IPTG) was added into the growth medium to induce the expression of proteins. The incubation was continued for $36 \mathrm{~h}$ at $20^{\circ} \mathrm{C}$ with shaking at $200 \mathrm{rpm}$. The recombinant strains were harvested by centrifugation and suspended at $50 \mathrm{mM}$ phosphate buffer, $\mathrm{pH}$ 7.6. Then, the solution was disrupted by sonication at ice condition. The total purification protocol was performed using the AKTA150 FPLC system (GE Healthcare, Madison, WI, USA). After removing the cell debris, the supernatant was collected and loaded onto the Ni-Sepharose affinity column (5 mL His-Trap ${ }^{\mathrm{TM}}$ High Performance, GE Healthcare, Madison, WI, USA), which was equilibrated previously. The impurity protein was removed using the washing buffer $(20 \mathrm{mM}$ imidazole, $20 \mathrm{mM}$ phosphate buffer, $500 \mathrm{mM} \mathrm{NaCl}, \mathrm{pH}$ 7.6). The active fractions were collected using the eluting buffer ( $150 \mathrm{mM}$ imidazole, $20 \mathrm{mM}$ phosphate buffer, $500 \mathrm{mM} \mathrm{NaCl}, \mathrm{pH}$ 7.6). To analyze the Mw and purity of the purified GalA, 10\% SDS-PAGE was used, and the PageRuler Prest Protein Ladder (Thermo Scientific, Waltham, MA, USA) was used as a protein standard marker.

\subsection{Characterization of Recombinant GalA}

The effect of $\mathrm{pH}$ and temperature on the purified GalA was analyzed as follows. The optimal reaction temperature of GalA was determined at the temperatures, ranging from 0 to $70{ }^{\circ} \mathrm{C}$ in $20 \mathrm{mM}$ phosphate buffer, $\mathrm{pH}$ 7.2. The optimal reaction $\mathrm{pH}$ of GalA was determined in $50 \mathrm{mM}$ citrate buffer ( $\mathrm{pH}$ 3.6-5.6), $50 \mathrm{mM}$ phosphate buffer (pH 5.8-7.4), $50 \mathrm{mM}$ Tris-HCl buffer ( $\mathrm{pH}$ 6.4-7.8) and $50 \mathrm{mM}$ Gly-NaOH buffer ( $\mathrm{pH} 8.0-9.6$ ), respectively. To determine the thermostability of the enzyme, GalA was pre-incubated at $30^{\circ} \mathrm{C}, 40{ }^{\circ} \mathrm{C}, 50^{\circ} \mathrm{C}$, or $60^{\circ} \mathrm{C}$ for various times. Then, the residual activity of the enzyme was determined at its optimal temperature and $\mathrm{pH}$. To analysis its $\mathrm{pH}$ stability, the enzyme solution was pre-incubated in various $\mathrm{pH}$ buffers $(\mathrm{pH} 3.4-9.6)$ at $4{ }^{\circ} \mathrm{C}$ for $12 \mathrm{~h}$. Then, the residual activity was measured under normal assay conditions. The effects of different metal ions and detergents on the enzyme activity of GalA were measured in the presence of various compounds $(1 \mathrm{mM})$ in the substrate solution. The substrate specificity of the GalA was determined using $5 \mathrm{mM}$ of five different substrates, including 4-Nitrophenyl- $\alpha$-d-galactopyranoside, 4-Nitrophenyl- $\beta$-d-glucopyranoside ONPG, PNPG, or 4-Nitrophenyl- $\beta$-d-xylopyranoside in $50 \mathrm{mM}$ sodium phosphate buffer ( $\mathrm{pH}$ 7.0) under the optimum conditions.

\subsection{Docking Analysis}

The 3D-structure of $\beta$-galactosidases GalA was built by the method of homology modeling using the Modeller 9.18 package (https://salilab.org/modeller/). The crystalline structure of $\beta$-galactosidases from E. coli (PDB ID: 6CVM) was chosen as the template. A total of 100 structures were built, and the structure with the best Discrete Optimized Protein Energy (DOPE) score was chosen for further docking analysis. The ligand (lactose) was drawn by ChemDraw V12.0. Then, the AutodockTool (The Scripps Research Institute, San Diego, CA, USA) was used for docking. The tool identifies novel binders by predicting their binding modes and affinities. Pymol was used to visualize the docking solutions and construct the graphical presentations and the figure illustrations. The conformation of lowest affinity value was chosen for further analysis in ligplot. 


\subsection{Activity Assay of $\beta$-Galactosidase}

The substrate, ONPG (Sigma Alddrich, St. Louis, MO, USA), was used for the $\beta$-galactosidase activity assay. Enzymatic activity was performed using $100 \mu \mathrm{L}$ enzyme and $900 \mu \mathrm{L}$ substrate $(0.3 \%$ $\left(\mathrm{w} / \mathrm{v}\right.$ ) in phosphate buffer, $\mathrm{pH} 7.0$ ) at $50{ }^{\circ} \mathrm{C}$ for $10 \mathrm{~min}$. Then, $200 \mu \mathrm{L}$ of $1 \mathrm{M} \mathrm{Na}_{2} \mathrm{CO}_{3}$ was added into the reaction mixture to end reaction. Then the reaction mixture was determined at OD $420 \mathrm{~nm}$ according to the ONP standard curve. One unit (U) of $\beta$-galactosidase was defined as the amount of enzyme required for the liberation of $1 \mu \mathrm{mol}$ ONP per minute under the assay conditions [47].

\subsection{Analysis of the Hydrolysis of Lactose and Galactooligosaccharides Production}

The reaction products of GalA towards lactose were determined by TLC analysis. Briefly, $100 \mu \mathrm{L}$ of purified GalA (100 U) was mixed into $900 \mu \mathrm{L}$ lactose substrate $(5 \mathrm{mg} / \mathrm{mL})$ and incubated for various times ( 0 and $30 \mathrm{~min}$, and 1, 2, 6, and $12 \mathrm{~h}$ ). Then, the reaction product was analyzed using TLC analysis on a HPTLC plate (Merck, Darmstadt, Germany) that was developed with a mixture n-butanol/formic acid/water (5:3:2, by vol) reagents. After drying and coloring at $80^{\circ} \mathrm{C}$ for $30 \mathrm{~min}$, the TLC plate was visualized with a solution of $90 \%(\mathrm{v} / \mathrm{v})$ ethanol and $10 \%(\mathrm{v} / \mathrm{v})$ sulfuric acid reagent. The hydrolysis of lactose in milk was determined by incubating $100 \mu \mathrm{L}$ purified GalA in $900 \mu \mathrm{L}$ of commercial skim milk (Inner Mongolia Yili Industrial Group Co. Ltd., Hohhot, China) at $50{ }^{\circ} \mathrm{C}$ for different times $(1,5,10$, and $15 \mathrm{~min}$ ) and then boiling the reaction mixture to end the reaction. The supernatant was analyzed by TLC analysis. To further analysis the ratio of GOS in the milk degrading of GalA, the reaction product at $15 \mathrm{~min}$ was analyzed by HPLC with a superdex peptide $10 / 300^{\mathrm{TM}}$ column. The reaction products of GalA were analyzed by SE-HPLC on the ÄKTA Avant 150 platform (GE Health, Chicago, IL, USA) using a Superdex peptide $10 / 300^{\mathrm{TM}}$ column (GE Health) equipped with a refractive index detector. The mobile phase was $0.2 \mathrm{M}$ ammonium bicarbonate. The column pressure was limited to $1.5 \mathrm{MPa}$ and the flow rate was $0.5 \mathrm{~mL} / \mathrm{min}$.

\subsection{Nucleotide Sequence Accession Numbers}

The $16 \mathrm{~S}$ rRNA gene sequence of Antarctic seawater bacterium Alteromonas sp. ANT48 and $\beta$-galactosidase gene (galA) were deposited in GenBank under the accession numbers MN332242 and MN337572, respectively.

\section{Conclusions}

In this study, we cloned and characterized a new GH2 $\beta$-galactosidase, GalA, from the Antarctic bacterium Alteromonas sp. ANT48. Our study demonstrated that the combined properties of GalA, being an optimal $\mathrm{pH}$ at 7.0 and stable at a $\mathrm{pH}$ range of 6.6-7.0, efficient lactose degrading ability, and high GOS yield make it an excellent candidate for further research and adaptation for commercial use. Further analyses will focus on elucidating the molecular mechanism of GalA yielding GOS, along with the determination of its three-dimensional structure. This approach also provides a theoretical basis for the preparation of other marine glycoside hydrolase enzymes.

Author Contributions: S.L. and M.X. designed the experiments; S.L. and X.Z. conducted the experiments; S.L. and M.X. analyzed the data; S.L. and M.X. wrote the main manuscript, and all authors reviewed the manuscript.

Funding: This research was funded by National Nature Science Foundation of China, grant number 31900031 and 41506218; Shandong Provencal Nature Science Foundation, grant number ZR2019BD027; Korea Research Fellowship Program, grant number 2019H1D3A1A01102881.

Conflicts of Interest: The authors state that there is no conflict of interest.

\section{References}

1. Saqib, S.; Akram, A.; Halim, S.A.; Tassaduq, R. Sources of $\beta$-galactosidase and its applications in food industry. 3 Biotech 2017, 7, 79. [CrossRef] [PubMed] 
2. Temuujin, U.; Chi, W.J.; Park, J.S.; Chang, Y.K.; Song, J.Y.; Hong, S.K. Identification and characterization of a novel $\beta$-galactosidase from Victivallis vadensis ATCC BAA-548, an anaetobic fecal bacterium. J. Microbiol. 2012, 50, 1034-1040. [CrossRef] [PubMed]

3. Splechtna, B.; Nguyen, T.H.; Steinböck, M.; Kulbe, K.D.; Lorenz, W.; Haltrich, D. Production of prebiotic galacto-oligosaccharides from lactose using $\beta$-galactosidases from Lactobacillus reuteri. J. Agric. Food Chem. 2006, 54, 4999-5006. [CrossRef] [PubMed]

4. Park, A.R.; Oh, D.K. Effects of galactose and glucose on the hydrolysis reaction of a thermostable $\beta$-galactosidase from Caldicellulosiruptor saccharolyticus. Appl. Microbiol. Biotechnol. 2010, 85, 1427-1435. [CrossRef]

5. Halbmayr, E.; Mathiesen, G.; Nguyen, T.H.; Maischberger, T.; Peterbauer, C.K.; Eijsink, V.G.H.; Haltrich, D. High-level expression of recombinant $\beta$-galactosidases in Lactobacillus plantarum and Lactobacillus sakei using a sakacin P-based expression system. J. Agric. Food Chem. 2008, 56, 4710-4719. [CrossRef]

6. Nguyen, T.H.; Splechtna, B.; Steinböck, M.; Kneifel, W.; Lettner, P.H.; Kulbe, K.D.; Haltrich, D. Purification and characterization of two novel $\beta$-galactosidases from Lactobacillus reuteri. J. Agric. Food Chem. 2006, 54, 4989-4998. [CrossRef]

7. Møller, P.L.; Jørgensen, F.; Hansen, O.C.; Madsen, S.M.; Stougaard, P. Intra- and extracellular $\beta$-galactosidases from Bifidobacterium bifidum and B. infantis: Molecular cloning, heterologous expression, and comparative characterization. Appl. Environ. Microbiol. 2001, 67, 2276-2283.

8. Kazemi, S.; Khayati, G.; Faezi-Ghasemi, M. $\beta$-galactosidase production by Aspergillus niger ATCC 9142 using inexpensive substrates in solid-state fermentation: Optimization by orthogonal arrays design. Iran. Biomed. J. 2016, 20, 287-294.

9. Nagy, Z.; Kiss, T.; Szentirmai, A.; Biro, S. $\beta$-galactosidase of Penicillium chrysogenum: Production, purification, and characterization of the enzyme. Protein Expr. Purif. 2001, 21, 24-29. [CrossRef]

10. Zhou, D.Z.K.; Chen, X.D. Effects of temperature and $\mathrm{pH}$ on the catalytic activity of the immobilized $\beta$-galactosidase from Kluyveromyces lactis. Biochem. Eng. J. 2001, 9, 33-40. [CrossRef]

11. Ray, I.; Gupta, M.N. Lactose hydrolysis by lactozym ${ }^{\mathrm{TM}}$ immobilized on cellulose beads in batch and fluidized bed modes. Process Biochem. 2003, 39, 325-332. [CrossRef]

12. Seddigh, S.; Darabi, M. Comprehensive analysis of beta-galactosidase protein in plants based on Arabidopsis thaliana. Turk. J. Biol. 2014, 38, 140-150. [CrossRef]

13. Priebe, M.G.; Zhong, Y.; Huang, C.; Harmsen, H.J.; Raangs, G.C.; Antoine, J.M.; Welling, G.W.; Vonk, R.J. Effects of yogurt and bifidobacteria supplementation on the colonic microbiota in lactose intolerant subjects. J. Appl. Microbiol. 2002, 104, 595-604.

14. Cantarel, B.L.; Coutinho, P.M.; Rancurel, C.; Bernard, T.; Lombard, V.; Henrissat, B. The carbohydrate-active enzymes database (CAZy): An expert resource for glycogenomics. Nucleic Acids Res. 2009, 37, 233-238. [CrossRef]

15. Juajun, O.; Nguyen, T.H.; Maischberger, T.; Iqbal, S.; Haltrich, D.; Yamabhai, M. Cloning, purification, and characterization of $\beta$-galactosidase from Bacillus licheniformis DSM 13. Appl. Microbiol. Biotechnol. 2011, 89, 645-654. [CrossRef]

16. Huber, R.E.; Kurz, G.; Wallenfels, K. A quantitation of the factors which affect the hydrolase and trangalactosylase activities of $\beta$-galactosidase (E. coli) on lactose. Biochemistry 1976, 15, 1994-2001. [CrossRef]

17. Juers, D.H.; Matthews, B.W.; Huber, R.E. LacZ $\beta$-galactosidase: Structure and function of an enzyme of historical and molecular biological importance. Protein Sci. 2012, 21, 1792-1807. [CrossRef]

18. Lukito, W.; Malik, S.G.; Surono, I.S.; Wahlqvist, M.L. From 'lactose intolerance' to 'lactose nutrition'. Asian Pac. J. Chin. Nutr. 2015, 24, S1-S8.

19. Felicilda-Reynaldo, R.F.; Kenneally, M. Digestive enzyme replacement therapy: Pancreatic enzymes and lactase. Medsurg. Nurs. 2016, 25, 182-185.

20. Heyman, M.B. Committee on Nutrition. Lactose intolerance in infants, children, and adolescents. Pediatrics 2006, 118, 1279-1286. [CrossRef]

21. Silanikove, N.; Leitner, G.; Merin, U. The interrelationships between lactose intolerance and the modern dairy industry: Global perspectives in evolutional and historical backgrounds. Nutrients 2015, 7, 7312-7331. [CrossRef] [PubMed]

22. Domingues, L.; Lima, N.; Teixeira, J.A. Aspergillus niger $\beta$-galactosidase production by yeast in a continuous high cell density reactor. Process Biochem. 2005, 40, 1151-1154. [CrossRef] 
23. Caputi, V.; Giron, M.C. Microbiome-Gut-Brain Axis and Toll-Like Receptors in Parkinson's Disease. Int. J. Mol. Sci. 2018, 19, 1689. [CrossRef] [PubMed]

24. Dembinski, A.; Warzecha, Z.; Ceranowicz, P.; Dembinski, M.; Cieszkowski, J.; Gosiewski, T. Synergic Interaction of Rifaximin and Mutaflor (Escherichia coli Nissle 1917) in the Treatment of Acetic Acid-Induced Colitis in Rats. Gastroenterol. Res. Pract. 2016, 2016, 3126280. [CrossRef]

25. Miskiewicz, A.; Ceranowicz, P. The Use of Liquids Ionic Fluids as Pharmaceutically Active Substances Helpful in Combating Nosocomial Infections Induced by Klebsiella pneumoniae New Delhi Strain, Acinetobacter baumannii and Enterococcus species. Int. J. Mol. Sci. 2018, 19, 2779. [CrossRef]

26. Ding, H.; Zhou, L.; Zeng, Q.; Yu, Y.; Chen, B. Heterologous expression of a thermostable $\beta$-1,3-galactosidase and its potential in synthesis of galactooligosaccharides. Mar. Drugs 2018, 16, 415. [CrossRef]

27. Ji, E.S.; Park, N.H.; Oh, D.K. Galacto-oligosaccharide production by a thermostable recombinant $\beta$-galactosidase from Thermotoga maritima. World J. Microbiol. Biotechnol. 2005, 21, 759-764. [CrossRef]

28. Talens-Perales, D.; Górska, A.; Huson, D.H.; Polaina, J.; Marín-Navarro, J. Analysis of domain architecture and phylogenetics of family 2 glycoside hydrolases (GH2). PLoS ONE 2016, 11, e0168035. [CrossRef]

29. Crittenden, R.G.; Playne, M.J. Production, properties and applications of food-grade oligosaccharides. Trends Food Sci. Technol. 1996, 7, 353-361. [CrossRef]

30. Warmerdam, A.; Paudel, E.; Jia, W.; Boom, R.M.; Janssen, A.E. Characterization of beta-galactosidase isoforms from Bacillus circulans and their contribution to GOS production. Appl. Biochem. Biotechnol. 2013, 170, 340-358. [CrossRef]

31. Yanahira, S.; Kobayashi, T.; Suguri, T.; Nakakoshi, M.; Miura, S.; Ishikawa, H.; Nakajima, I. Formation of oligosaccharides from lactose by Bacillus circulans beta-galactosidase. Biosci. Biotechnol. Biochem. 1995, 59, 1021-1026. [CrossRef] [PubMed]

32. Jorgensen, F.; Hansen, O.C.; Stougaard, P. High-efficiency synthesis of oligosaccharides with a truncated beta-galactosidase from Bifidobacterium bifidum. Appl. Microbiol. Biotechnol. 2001, 57, 647-652. [PubMed]

33. Song, J.; Imanaka, H.; Imamura, K.; Minoda, M.; Katase, T.; Hoshi, Y.; Yamaguchi, S.; Nakanishi, K. Cloning and expression of a beta-galactosidase gene of Bacillus circulans. Biosci. Biotechnol. Biochem. 2011, 75, 1194-1197. [CrossRef] [PubMed]

34. Karan, R.; Capes, M.D.; DasSarma, P.; DasSarma, S. Cloning, overexpression, purification, and characterization of a polyextremophilic $\beta$-galactosidase from the Antarctic haloarchaeon Haloruburm lacusprofundi. BMC Biotechnol. 2013, 13, 3. [CrossRef] [PubMed]

35. Shumway, M.V.; Sheridan, P.P. Site-directed mutagenesis of a family $42 \beta$-galactosidase from an Antarctic bacterium. Int. J. Biochem. Mol. Biol. 2012, 3, 209-218. [PubMed]

36. Hildebrandt, P.; Wanarska, M.; Kur, J. A new cold-adapted beta-D-galactosidase from the Antarctic Arthrobacter sp. 32c-Gene cloning, overexpression, purification and properties. BMC Microbiol. 2009, 9, 151. [CrossRef] [PubMed]

37. Xu, K.; Tang, X.; Gai, Y.; Mehmood, M.; Xiao, X.; Wang, F. Molecular characterization of cold-inducible beta-galactosidase from Arthrobacter sp. ON14 isolated from Antarctica. J. Microbiol. Biotechnol. 2011, 21, 236-242.

38. Lee, D.H.; Kang, S.G.; Suh, S.G.; Byun, J.K. Purification and characterization of a beta-galactosidase from peach (Prunus persica). Mol. Cells 2003, 15, 68-74.

39. Husain, Q. Beta galactosidases and their potential applications: A review. Crit. Rev. Biotechnol. 2010, 30, 41-62. [CrossRef]

40. Chen, W.; Chen, H.; Xia, Y.; Zhao, J.; Tian, F.; Zhang, H. Production, purification, and characterization of a potential thermostable galactosidase for milk lactose hydrolysis from Bacillus stearothermophilus. J. Dairy Sci. 2008, 91, 1751-1758. [CrossRef]

41. Hoyoux, A.; Jennes, I.; Dubois, P.; Genicot, S.; Dubail, F.; Francois, J.M.; Baise, E.; Feller, G.; Gerday, C. Cold-adapted beta-galactosidase from the antarctic psychrophile Pseudoalteromonas haloplanktis. Appl. Environ. Microbiol. 2001, 67, 1529-1535. [CrossRef] [PubMed]

42. Maischberger, T.; Leitner, E.; Nitisinprasert, S.; Juajun, O.; Yamabhai, M.; Nguyen, T.H.; Haltrich, D. Beta-galactosidase from Lactobacillus pentosus: Purification, characterization and formation of galacto-oligosaccharides. Biotechnol. J. 2010, 5, 838-847. [CrossRef] [PubMed] 
43. Iqbal, S.; Nguyen, T.H.; Nguyen, T.T.; Maischberger, T.; Haltrich, D. beta-Galactosidase from Lactobacillus plantarum WCFS1: Biochemical characterization and formation of prebiotic galacto-oligosaccharides. Carbohydr. Res. 2010, 345, 1408-1416. [CrossRef] [PubMed]

44. Hsu, C.A.; Lee, S.L.; Chou, C. Enzymatic production of galactooligosaccharides by $\beta$-galactosidase from Lactobacillus pentosus purification characterization and formation of galacto-oligosaccharides from Bifidobacterium longum BCRC 15708. J. Agric. Food Chem. 2007, 55, 2225-2230. [CrossRef] [PubMed]

45. Mahdian, S.M.A.; Karimi, E.; Tanipour, M.H.; Parizadeh, S.M.R.; Glayour-Mobarhan, M.; Bazaz, M.M.; Mashkani, B. Expression of a functional cold active $\beta$-galactosidase from Planococcus sp.-L4 in Pichia pastoris. Protein Expr. Purif. 2016, 125, 19-25. [CrossRef]

46. Mahoney, R.R. Enzymes exogenous to milk in dairy, $\beta$-D-galactosidase. Encycl. Dairy Sci. 2003, 2, 907-914.

47. Sun, J.; Yao, C.; Wang, W.; Zhuang, Z.; Liu, J.; Dai, F.; Hao, J. Cloning, expression and characterization of a novel cold-adapted $\beta$-galactosidase from the deep-sea bacterium Alteromonas sp. ML52. Mar. Drugs 2018, 16, 469. [CrossRef]

(C) 2019 by the authors. Licensee MDPI, Basel, Switzerland. This article is an open access article distributed under the terms and conditions of the Creative Commons Attribution (CC BY) license (http://creativecommons.org/licenses/by/4.0/). 